\title{
TEACHERS' OPINIONS REGARDING TEACHING AN INTEGRATED OPTIONAL DISCIPLINE (IOD) IN ROMANIAN SECONDARY SCHOOLS
}

\author{
Alina Ioana CONSTANTIN, PhD student \\ University of Bucharest, Romania \\ alina constantin2004@yahoo.com, \\ Maria GOGA, Ph.D., \\ University of Civil Engineering of Bucharest, Romania \\ goga.maria@yahoo.com
}

\begin{abstract}
Curriculum integration is a necessity. In everyday life, problem solving requires knowledge, diverse skills that cannot be acquired by studying only individual disciplines, with no connections between them. This study explores the views of the teachers in the secondary schools, in Romania, on teaching an integrated optional discipline. We have designed and carried out a mixed research - quantitative and qualitative, based on several objectives focused on teachers' opinions to teach an $I O D$, the required competencies to teach an IOD, their perceived barrieres in teaching an IOD and possible solutions to overcome those barriers. We did our research in 18secondary schools from Bucharest city and five counties, on a sample of 153 teachers. The results of the research show that only few teachers teach IOD in Romania. In order to teach an IOD, they need to have social skills and creativity besides knowlege from different areas. Theachers state that there is a lack of curricular resources and time to prepare the lessons. Also, they have difficulties in making connections between the knowlege from different areas. Teachers consider that in order to solve these problems, they need to help each other, to study more and suggest that schools must support them with diverse curricular materials.
\end{abstract}

Key words: competencies; integrated curriculum; obstacles; secondary schools; teaching an integrated optional discipline;

\section{Introduction}

Curriculum integration represents "the connection of school disciplines in order to avoid their traditional isolation", as well as "the process and the outcome of the process by which the student interprets the subject matter based on his or her life experience and knowledge which has already mastered them" (Legendre, 1993, as cited in Ciolan, 2008, p. 116).

Integrated curriculum is a necessity. In everyday life, problem solving requires knowledge, diverse skills that cannot be acquired by studying only individual disciplines, with no connections between them. Moreover, in a rapidly changing society in which the global connection has grown significantly, knowledge from different areas, the ability to solve problems, critical thinking and the ability to communicate effectively are needed (Wagner, Baum, Newbill, 2014).

J. Dewey, the pioneer of the curriculum integration, considered that the student has to learn only what makes sense to him or to her, something that widens his or her horizons (Dewey, 1977) and he realised that there must be a connection between the school and the social community in which it resides (Dewey, 1972). For this, for example, it is necessary 
that "the questions, the chemical and physical problems that arise in the kitchen" to be "brought to the laboratories for study" (Dewey, 1977, p. 129).

Iosifescu (2012), reflecting on the current mission of school, believed that it "has to form autonomous individuals involved in the process of knowledge and capable of contextualizing responses to a wide diversity of situations and tasks" (p.125). Therefore, it is necessary to develop transversal competencies that facilitate the transfer of knowledge and skills from one discipline to another, from school to everyday life. How do we develop transversal skills? By changing the angle from which we perceive teaching and learning, these need to be "seen from a holistic perspective, reflecting the real world." (Shoemaker, as cited in Ciolan, 2008, p.117).

\section{Teachers' competencies in curriculum integration}

At this moment we could not identify any study regarding the teachers' necessary competencies to teach an integrated optional discipline, but we will create a list of those competencies from the study of the benefits of curriculum integration.

"Why integrate the curriculum?" is the question that many researchers, specialists in education have asked. The answer is, in short: because integrated curriculum enhances knowledge, it diminishes the fragmentation of the student program (Jacobs, 1989), and knowledge (Potolea, 1983); gives relevance to the curriculum and learning (Jacobs, 1989; Drake \& Burns, 2004; John, 2015), rigor of content, despite apparent superficiality (Drake \& Burns, 2004); facilitates meaningful learning contexts (Beane, 2005, as cited in Dowden, 2010).

Through curricular connections (DeMoss \& Morris, 2002, as cited in Munroe, 2015; Mason, 1996, as cited in Hall-Kenyon \& Smith, 2013), connections to real life (John, 2015), stimulating learning opportunities (Furner \& Kumar, 2007) in different contexts (Potolea, 1983), curriculum integration contributes to increasing learning efficiency and fosters the intrinsic motivation of knowledge (Potolea, 1983; Veblen \& Elliott, 2000, as cited in Munroe, 2015; Gresnigt et al, 2014). "Often students cannot solve problems because they do not understand the context in which the problems are embedded." (Frykholm \& Glasson, 2005, as cited in Furner \& Kumar, 2007, p. 186); students who benefit of an integrated curriculum learn with pleasure (John, 2015), gaining cognitive skills (Gresnigt et al, 2014; Stohlman, Moore, Roehrig, 2012), emotional skills (Gresnigt et al, 2014), social skills and creativity (Stohlman, Moore, Roehrig, 2012). Relations between teachers and students are strengthened, and the results of quality learning confer dignity to students (Beane, 2005, as cited in Dowden, 2010).

Another benefit of curriculum integration, as seen by the National Herbart Society in 1895 , is that it represents a possible solution to the following three problems:

What is worth knowing, given the huge increase in available knowledge? What is important to be able to do, given a huge increase in the number of students needing education to be productive in the workplace? How can schools teach moral character if teachers cannot relate curriculum to the real world?

(Wraga, 1996, 1997, as cited in Drake \& Burns, 2004, p.19).

Based on all above mentioned benefits, we have sketched a list of competencies that teachers need to own in order to teach an IOD, as follows: knowledge from different areas; the ability to make connections between disciplines and between disciplines and real life; the ability to recognise and explore relevant and meaningful knowledge and learning 
contexts; openness to integrated curriculum; commitment; critical thinking; problem solving; efficient communication; collaboration; creativity.

\section{Implications of curriculum integration}

Hulstrand (2012) considered the curriculum integration as a marathon. In this context, we see the curriculum integration as a source of life because it energizes teachers and students in the process of teaching-learning-evaluation (on the one hand) and brings to school events, experiences, abilities from everyday life (on the other hand). However, a careful and long-term preparation for teaching is required, otherwise several factors could hinder it. These factors are:

- Lack of time (Munroe, 2015; John, 2015);

- A lot of practice (John, 2015);

- Teacher motivation and commitment (Gresnigt et al, 2014);

- Professional development of teachers (Gresnigt at al, 2014) and prospective teachers (John, 2015);

- Profession development of all stakeholders such as: principals, senior teachers, grade teams, parents, administrators, curriculum supervisors, school supervisors (John, 2015);

- Teachers support given by:a)school principals, that do not make sufficient provisions for funding the teachers' training and material base. (Gresnigt et all, 2014); b)universities that are not assisting sufficiently teachers in classrooms and teachers trainings (Rogers \& Portsmore, 2004; Cantrell et al., 2006; Nugent et al., 2010, as cited in Stohlman, Moore, Roehrig, 2012); c) their colleagues (Potolea, 1983); p. 68);

- Lack of time/space within the existing curricula and timetables (Gresnigt et all, 2014,

- Lack of explicit training (John, 2015, p. 186),

- Dedicated, organized and knowledgeable individuals (Stohlman, Moore, Roehrig, 2012, p. 32).

\section{Problem Statement}

In teaching/learning content in pre-university education, the tendency to organize the disciplines from an integrated perspective is increasingly present. This is possible due to the framework plan that is structured on curricular areas (Language and Communication, Mathematics and Natural Sciences, Human and Social Sciences, Arts, Physical Education, Sports and Health, Technologies, Counselling and Guidance), which expresses the intention to find solutions for content integration. Moreover, one of the principles behind the elaboration of the framework plan is the principle of combining disciplinary approaches with multi-, inter-, and transdisciplinary approaches (Potolea, Toma \& Borzea, 2012). This principle is reflected in the new framework plan at the secondary level, which entered into force in September 2017 in Romania, which provides for an IOD at a level of each curricular area, as well as the existence of an IOD at the level of several curricular areas, the student being able to opt for 1 - 4 IODs, of which at least one at the level of several curricular area is compulsory (OMENCS 3590, 2016).

According to the educational policy document on the design and updating of the new National Curriculum, an IOD is "a new discipline, structured around an integrative theme for a certain curricular area or for several curricular areas" (ISE, 2015, p. 32).

In 2018, just one year after implementation, the obligation of studying an IOD has been removed. (OMEN 4828, 2018) Why? Maybe the teachers do not have the necessary competencies and experience to teach an IOD? Maybe there are different issues such as lack of time, practice, material or financial resources. 
In this article we present a research to find out the issues that make it difficult to teach an IOD in the Romanian educational context. We should mention that there are only few studies in the existing literature regarding teaching IOD in Romania. Therefore the current paper fills this gap that currently exists.

\section{Research methodology}

In this section we will present first the objectives, the hypothesis, then the research instruments, and the sampling of the research.

Objectives

- Identification of teachers' opionins regarding teaching an IOD;

- Identification of teachers' level of knowledgein teaching an IOD;

- Identification of teachers' level of class experience in teaching an IOD;

- Identification of the obstacles and possible remedial solutions in teaching an IOD.

\section{Hypothesis}

We assume that a low number of teachers teaches an IOD due to the lack of expertise and experience in curriculum integration.

\section{Research methods}

A questionnaire-based survey addressed to secondary teachers was design and applied for collecting the data. The first part of it included six questions collecting data about the respondents (such as the school and locality where he/she teaches, the discipline from the core curriculum taught by he/she, teaching experience, studies and didactic grade) and the second part included closed and open-ended questions in order to identify the teachers' views and opinions: teachers' options for teaching an IOD, the way the respondents teach an IOD, the way that the respondents acquire

\begin{tabular}{|c|c|c|c|c|}
\hline $\begin{array}{l}\text { No.c } \\
\text { rt. }\end{array}$ & City & $\begin{array}{l}\text { District/C } \\
\text { ounty }\end{array}$ & School & $\begin{array}{c}\begin{array}{c}\text { No of } \\
\text { teachers }\end{array} \\
\end{array}$ \\
\hline 1 & \multirow[t]{12}{*}{$\begin{array}{l}\text { Buchare } \\
\text { st }\end{array}$} & \multirow[t]{5}{*}{ District 1} & Nicolae Titulescu & 12 \\
\hline 2 & & & Geo Bogza & 17 \\
\hline 3 & & & Petre Ispirescu & 6 \\
\hline 4 & & & Sf. Nicolae & 7 \\
\hline 5 & & & Eugen Barbu & 8 \\
\hline 6 & & \multirow[t]{4}{*}{ District 3} & Leonardo Da Vinci & 15 \\
\hline 7 & & & Cezar Bolliac & 8 \\
\hline 8 & & & No 78 & 7 \\
\hline 9 & & & Al. I. Cuza & 4 \\
\hline 10 & & District 5 & No 131 & 9 \\
\hline 11 & & \multirow[t]{2}{*}{ District 6} & No 206 & 9 \\
\hline 12 & & & CN Elena Cuza & 7 \\
\hline 13 & Voluntari & Ilfov & No 1 & 3 \\
\hline 14 & Urziceni & Ialomița & I. H. Radulescu & 10 \\
\hline 15 & Scrioastea & Teleorman & Anghel Manolache & 11 \\
\hline 16 & Filiași & Dolj & Filiasi & 17 \\
\hline 17 & Ploiești & Prahova & CN Al. I. Cuza & 2 \\
\hline 18 & Câmpina & Prahova & Ion Campineanu & 1 \\
\hline \multicolumn{4}{|c|}{ TOTAL OF TEACHERS } & 153 \\
\hline
\end{tabular}

Table 1: The schools involved in the research

their knowledge in curriculum integration, their competencies needed to teach an IOD, their experience in teaching an IOD, the obstacles that the respondents who teach an IOD meet and suggestions for possible remedies, the reason why some respondents do not teach an IOD.

Due to the 
nature of the applied questionaire (more than half of the questions have opened answers), we consider that we have been conducted a mixed research - quantitative and qualitative research.

\section{Sampling}

The sampling method used in this research was the snowball one (Noy, 2008).

We did our research in $\mathbf{1 8}$ secondary schools, located in Bucharest city and $\mathbf{5}$ counties, on a sample of $\mathbf{1 5 3}$ teachers, as following (Table 1):

In Table 1 we have the teacher distribution according to the place where they teach. Most of the respondents are from Bucharest, followed by those from the other counties (Dolj, Teleorman, Ialomița, Prahova, and Ilfov).

Further we will present the respondents' identification data. The data that we collected about teachers are the followings: teaching experience, studies, didactic degree and taught discipline from the core curriculum.

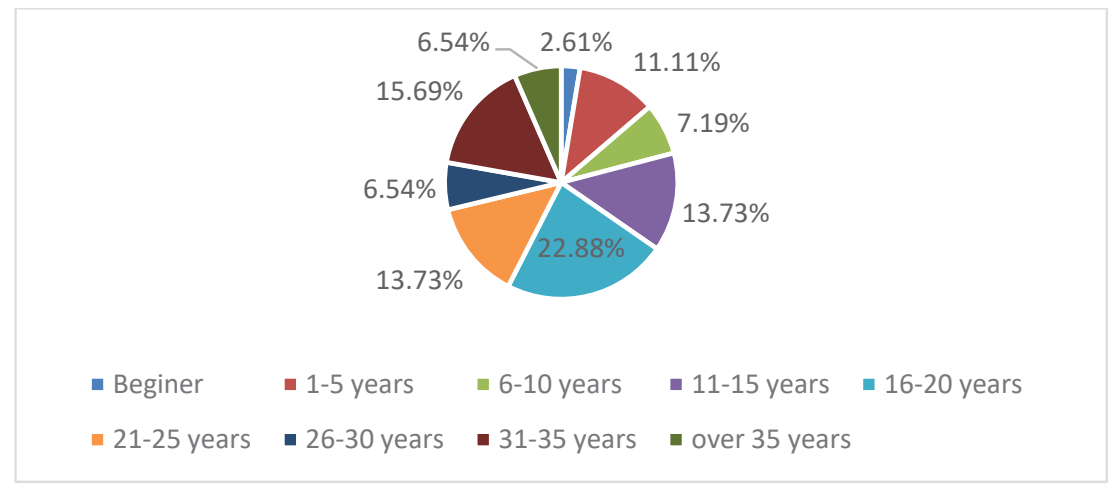

Figure 1: Teaching experience of the respondents

As we can see in the Figure 1, the teaching experience of our teachers is mixed. Most of them $(22,8 \%)$ are beginners in the teaching process. Around $16 \%$ of the respondents have between 31 and 35 years of teaching. At the same percentage (13,73\%) we find the number of teachers with 11-15 years and 21-25 years of teaching. We can conclude that our respondents have a working experience that varies a lot. They are both career debutants and experienced people who can contribute with consistent information on curriculum integration.

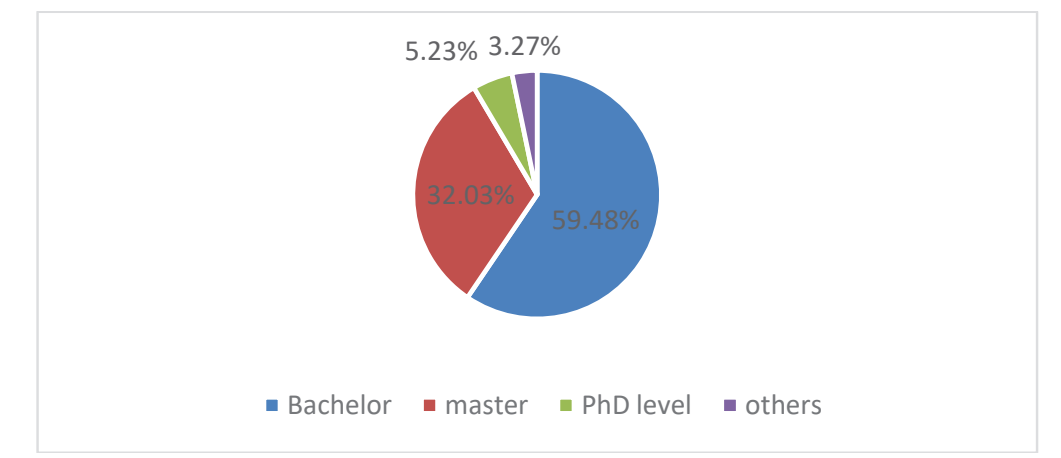

Figure 2: The level of educational studies of the teachers

The Figure 2 of this paper shows us that most of the respondents $(59,48 \%)$ have only bachelour degree, 32,03\% master degree, and only 5,23\% $\mathrm{PhD}$ level. 


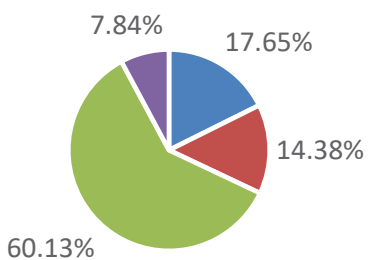

- Permanent - grade II - grade I - other levels

Figure 3: The didactic degree of the professional experience of the teachers

Tabel 2: Different disciplines taught by respondents

\begin{tabular}{|c|c|c|}
\hline $\begin{array}{l}\text { Curriculum } \\
\text { Area }\end{array}$ & Discipline & $\begin{array}{r}\text { No. } \\
\text { Teachers }\end{array}$ \\
\hline \multirow[t]{4}{*}{$\begin{array}{l}\text { Language and } \\
\text { communication }\end{array}$} & Romanian Language and Literature & 23 \\
\hline & English language & 15 \\
\hline & French & 7 \\
\hline & Italian language & 1 \\
\hline \multirow[t]{4}{*}{$\begin{array}{l}\text { Mathematics and } \\
\text { natural sciences }\end{array}$} & Math & 22 \\
\hline & Physics & 7 \\
\hline & Chemistry & 6 \\
\hline & Biology & 8 \\
\hline \multirow[t]{4}{*}{ Man and society } & History & 9 \\
\hline & Geography & 8 \\
\hline & Social Education and Civic Culture & 8 \\
\hline & Religion & 15 \\
\hline \multirow[t]{2}{*}{ Arts } & Art education & 5 \\
\hline & Musical education & 3 \\
\hline \multirow[t]{2}{*}{ Technologies } & Technological education & 5 \\
\hline & Informatics and ICT & 1 \\
\hline $\begin{array}{l}\text { Physical } \\
\text { education, sports and } \\
\text { health }\end{array}$ & Physical education and sport & 7 \\
\hline Not specified & & 3 \\
\hline TOTAL & & 153 \\
\hline
\end{tabular}

We wanted to know what is the didactic degree of the professional experience of our respondents. We realised, from the Figure 3, that most of our teachers $(60,13 \%)$ have the highest degree (grade I). This degree is recognized in the Romanian educational context as the highest for teachers. It is attributed to those teachers with many years of teaching and a high knowledge level in the taught subject matter.

In Table 2 we

have the list of the subject matters taught by our respondents. Most of them are Romanian Language and Literature teachers (23), Math teachers (22) or Religion and English language teachers (15). We can see that all Romanian curricular areas are covered by our respondents in the teaching process.

\section{Findings and discussions}

We have analyzed the collected data and explored the teachers' opinions, following the objectives and hypothesis formulated at the beginning of the research. We will present our findings in relation to the research objectives presented previously.

Objective no 1: Identification of teachers' opinions for teaching an IOD Teaching an IOD 
From the 153 teachers, only $19.61 \%$ said that they were teaching an IOD, while $80.39 \%$ of them did not teach. We observed that there are quite few teachers that teach an integrated optional discipline.

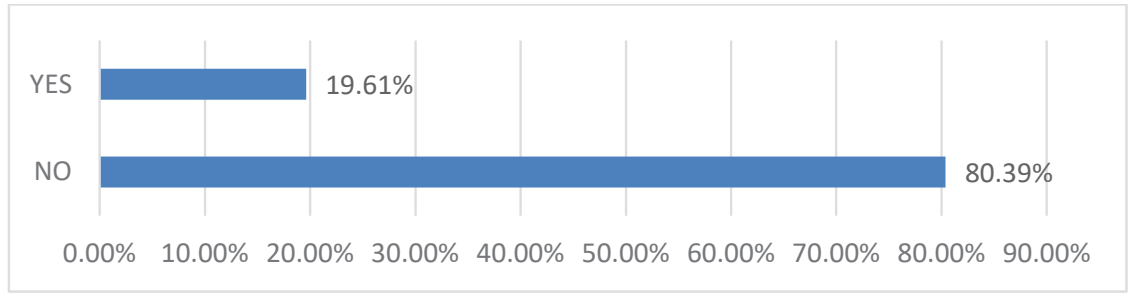

Figure 4: Teachers availability for teaching an IOD

\section{Ways to teach the IOD}

We wanted to know the opinions of the teachers that teach an IOD regarding the ways of teaching it. As we can see in the Figure 5, more than half of the teachers $(53.33 \%)$ teach alone this kind of disciplines, $33.33 \%$ teach taking into account the collaborators' advice, and less than $14 \%$ said that they teach in team. We observe that almost $50 \%$ of the teachers need support from other teachers or advisors to teach integrated disciplines.

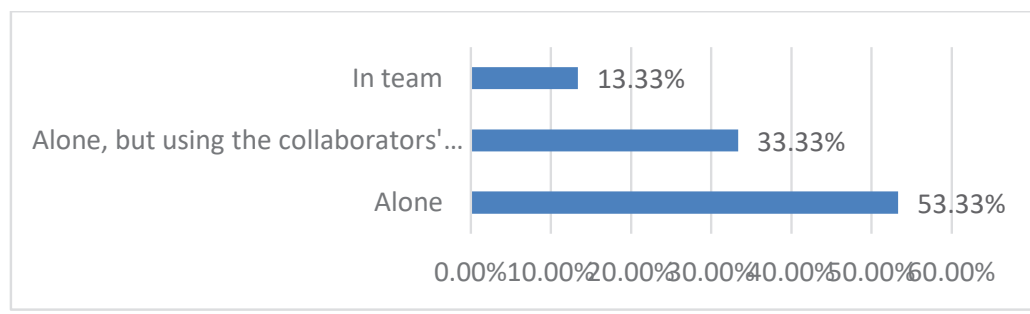

Figure 5: How do teachers teach the IOD

\section{$>\quad$ Reasons for which the teachers do not teach an IOD}

We were interested what reasons have the teachers that do not teach an IOD. We discovered (Figure 6) that most of them (69.75\%) do not teach an IOD because they were not requested, 24.37\% invoked other reasons such asonethat the Romanian school is not ready for this approach and moreover the framework curriculum provides a maximum of hours for each class, which limits the inclusion of an IOD. Around 5\% of the teachers acknowledged that they do not have the necessary skills. A very small percentage $(1.68 \%)$, even if they were required to teach an IOD and have the necessary skills, declined because the proposed area has a low professional interest for them.

At this level we can conclude that an IOD is a really challenge for Romanian teachers.

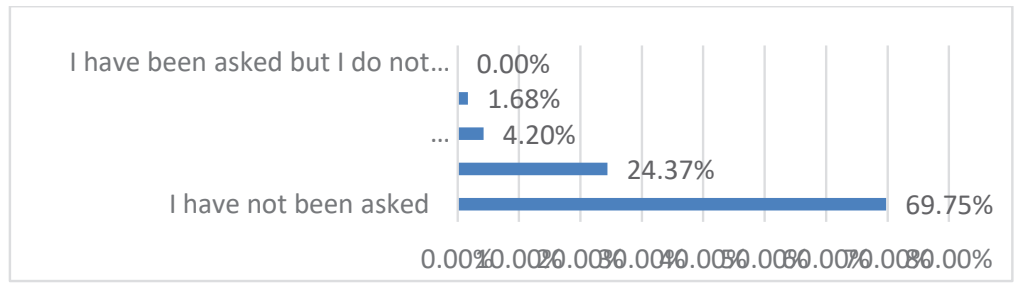

Figure 6: Teachers' reasons for not teaching an IOD 


\section{Objective no 2: Identification of teachers' level of knowledge in teaching an IOD How teachers acquire the necessary knowledge to teach an IOD}

Those teachers that teach IODs were asked to tell us how do they acquire the knowledge for it. In the Figure 7 we discovered that almost half of the teachers $(46.94 \%)$ improved their performance through individual study. Taking some other courses $(42.86 \%)$ is another alternative, but we do not know which type of courses the teachers mention. Few

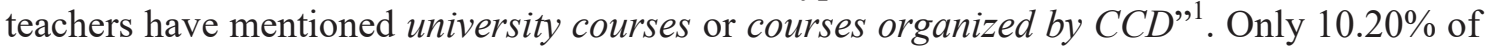
the answers make reference to teaching experience. We can see that teaching an integrated discipline is optional and every teacher will prepare to teach this kind of discipline in different ways, from individual studies to university level or courses from different educational institutions.

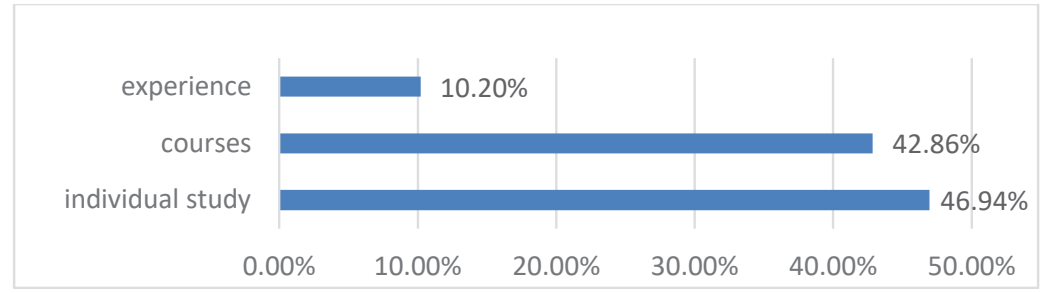

Figure 7: How teachers acquire the necessary knowledge to teach an IOD

\section{Competencies required to teach an IOD}

For our research it was very important to know from the teachers' point of view what are the competencies required to teach an IOD. The teachers that teach an IOD have a varied range of the necessary competencies in teaching an IOD (Figure 8). For example, they consider extremely important the attitudes towards students $(25 \%)$ such asthe desire to make students understand things, the ability to capture attention, engagement through games and applications, closeness to student's needs, the ability to stimulate children to collaborate and work in a team, the desire to involve students in specific activities. Other competencies (also identified by us and mentioned in our list) suggested by the teachers are social skills, creativity \& problem solving skills $(14,29)$. The third place $(12,50 \%)$ is occupied by the knowledge competencies regarding the taught discipline. The teachers also mentioned various attitudes $(10,71 \%)$ such as seriousness, discipline, sense of initiative, openness to the new and good things, respect for the values of the past, dedication, interest in environmental protection, passion for profession, desire for improvement / development, and adaptability.

To teach IODs is a really challenge for teachers in Romanian secondary schools. They know that the knowledge is less important in comparison with others competencies such as creativity, the desire to make students understand things, desire for improvement/development, and adaptability, engagement through games and applications.

\footnotetext{
${ }^{1}$ CCD stands for The Teacher Training Centerwhich is a resource center aiming at the professional and personal development and development of the employees of the pre-university education system in Romania.
} 


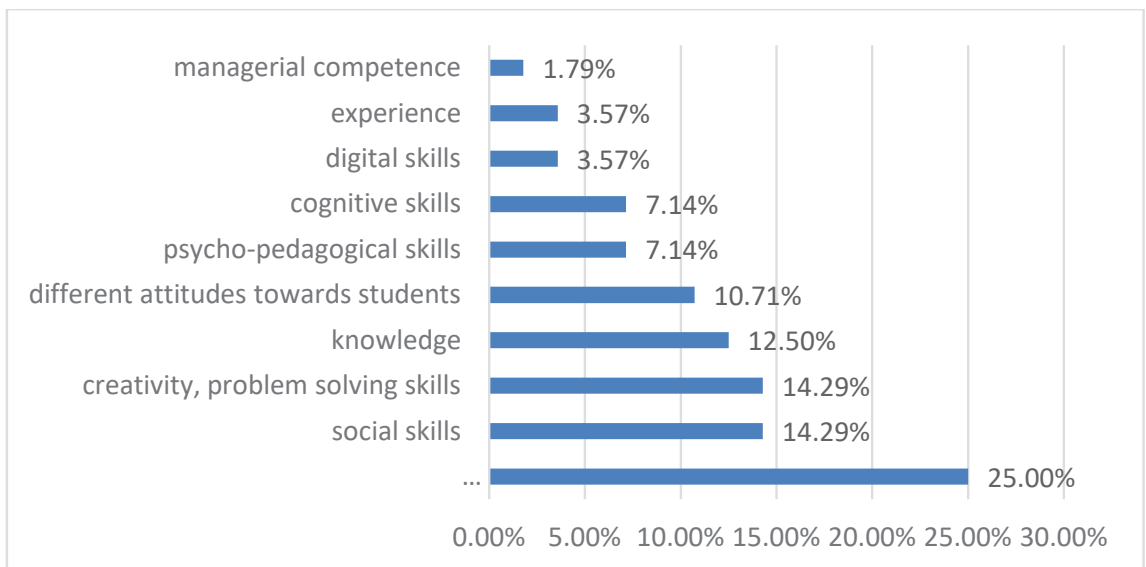

Figure 8: Teachers' competencies for teaching an IOD

\section{Objective no 3: Identification of teachers' level of classs experience in teaching an IOD \\ Teachers' experience in teaching an IOD}

We observed, in the Figure 9, that most of the teachers $(65.52 \%)$ have been teaching IOD for 1-2 years. Fewer percentages are seen for teachers that teach from 7-8 years $(10,34 \%)$ or $9-10$ years $(6,9 \%)$. We can conclude from this that teachers are required to teach in the last two years and also that an IOD is something new for most of the teachers.

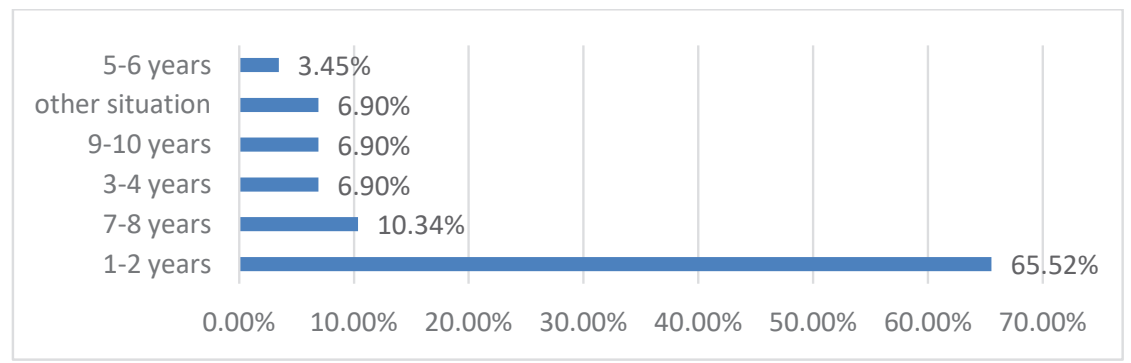

Figure 9: Teachers' experience in teaching an IOD

\section{Objective no 4: Identification of the obstacles and possible remedial solutions in teaching an IOD}

\section{The main obstacles the teachers have encountered in teaching an IOD}

From the teachers that teach an IOD we observe (Figure 10) that one-third of respondents feel that they did not encounter obstacles while teaching an IOD, and another third think they have no curricular resources. However, only $15.63 \%$ of the teaching staff involved in our research encountered a major obstacle that is also mentioned in various international studies - difficulty in selecting, explaining, making connections between knowledge. (Been, 2005, as cited in Dowden, 2010; DeMoss \& Morris, 2002, as cited in Monroe, 2015).

Some of the main obstacles mentioned by teachers are: the lack of auxiliaries, textbooks and authors who focused on the integrated curriculum; the time allocated to analysing the optional and synthesizing the information according to the level of the class of students; difficulties in gathering the information necessary for the discipline, making 
students make connections, finding interactions between information, and explaining certain notions.

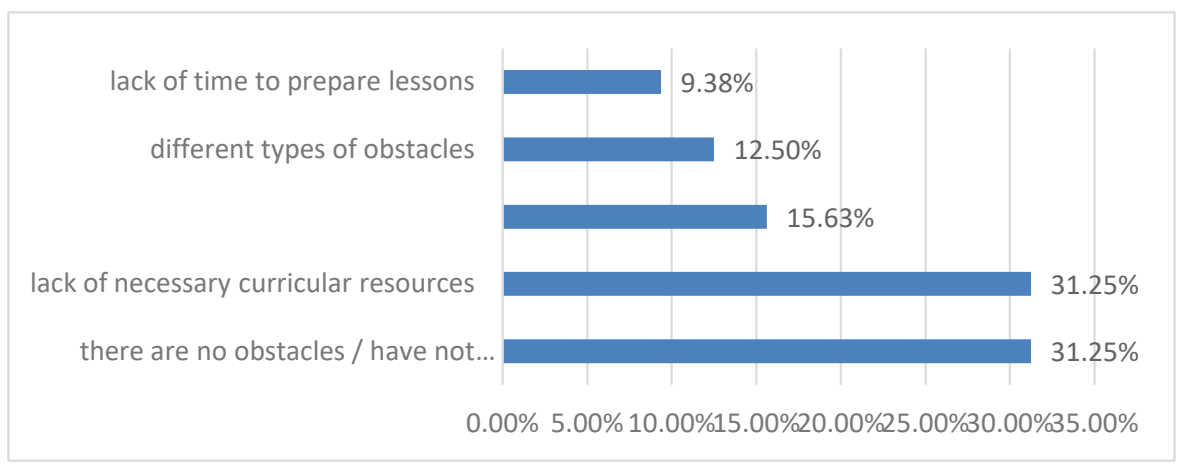

Figure 10: Types of obstacles in teaching an IOD

\section{Types of possible remedies for obstacles in teaching an IOD}

The solutions that were identified (Figure 11) are as follows: collaboration between teachers, parents and students $(36.84 \%)$, providing the school with curricular and material resources $(31.58 \%)$, and greater involvement of teachers $(31,58 \%)$.

First of all, teachers believe that it is necessary to equip schools with the necessary resources to deliver integrated options, such as: organizing tutorials, accessibility to educational platforms, writing manuals and accessing them in electronic format, editing books on the integrated curriculum, of the school. At the same time it is necessary to teach together with other colleagues and to collaborate with parents and former students.

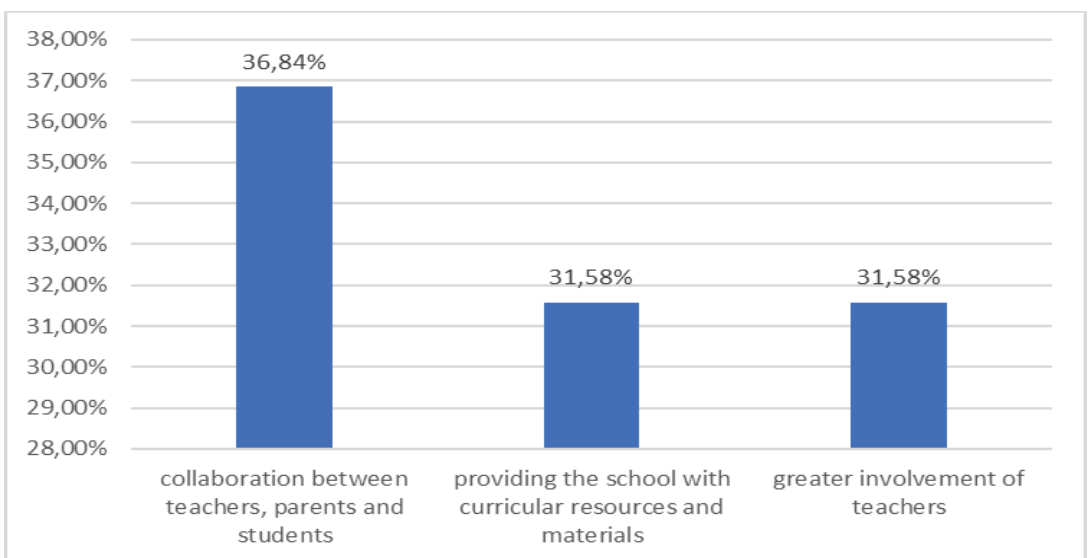

Figure 11: Types of possible remedies for obstacles in teaching an IOD

\section{Conclusions}

We did a research with 153 teachers from 18 secondary schools located in Bucharest and 5 counties. Following the analysis of the given answers, we made few conclusions based on the research objectives, as follows:

- A very small number of teaching staff is involved in teaching an IOD. This validates also our hypothesis that a small number of teachers participates in teaching IOD;

- The main reason teachers do not teach an integrated option is that they were not "asked for this"; however, the involvement of a small number of teachers in teaching an integrated discipline is also due to the lack of teaching space in the timetable, with the framework plan providing only 1-4 hours a week for an IOD. This lack of space was also identified by Gresnigt et all (2014); 
- Around three-fourth of the teachers teaching an IOD consider that they have sufficient knowledge; the main competencies identified by teachers being social competencies, creativity, and problem solving ones. We observe that some of the competencies we identified as requiring for teaching an IOD (see our list of competencies from Introduction) are found in the competencies that teachers believe they have acquired.

- Although three-fourth of teachers that teach an integrated discipline think they have the necessary experience, more than half of them have been teaching IOD only from 1-2 years;

- Around one-third of teachers teaching an IOD say they have encountered no obstacles. Another one-third thinks that it does not have the necessary curricular resources and proposes that the school to be adequately equipped with the necessary curricular resources. This problem, as well as the remedy proposed by teachers, was identified also by Gresnigt et al (2014) as factors that may disrupt the implementation of an integrated curriculum.

- Another obstacle recognized by respondents is the difficulty of selecting, explaining and linking content, which in fact represents an important skill needed for teaching an integrated discipline, is also observed by Been (2005, as cited in Dowden, 2010) and DeMoss \& Morris (2002, as cited in Monroe, 2015).

\section{References}

Ciolan, L. (2008). Invățarea integrată. Fundamente pentru un curriculum transdisciplinar. Iași: Editura Polirom;

Dewey, J. (1972). Democrație și educație. O introducere în filosofia educației. București: Editura Didactică și Pedagogică;

Dewey, J. (1977). Trei scrieri despre educație. Copilul și curriculumul. Școala și societatea. Experiență și societate. București: Editura Didactică și Pedagogică;

Dowden, T. (2010). Integrated curriculum in Aotearoa New Zealand: Rediscovering the potential of student-centered curriculum design in the middle years. Australian Journal of Middle Schooling, 10(2), pp. 4-10;

Drake, S. M.; Burns, R. C. (2004). Meeting standards through integrated curriculum. Virginia: ASCD;

Furner, J., \& Kumar, D. (2007). The mathematics and science integration argument: a stand for teacher education. Eurasia Journal of Mathematics, Science \& Technology, 3(3), 185 189 ;

Gresnigt, R. et al. (2014). Promoting science and technology in primary education: a review of integrating curricula. Studies in Science Education Journal, Vol. 50, No. 1, pg. 47-84;

Hall-Kenyon, K. M., Smith, L. K. (2013). Negotiating a shared definition of integrated curriculum: a self -study of two teacher educators from different disciplines. Teacher Education Quarterly, Spring 2013, pg. 89-108;

Hulstrand, J. (2012). Integrated curriculum: It's a marathon, not a sprint. International Educator, ProQuest Central, Sept/Oct 2012, 21, 5; pag. 48-51;

Iosifescu, Ș. (2012). Analiza mediului școlar în raport cu implementarea reformei curriculare. București: CNEE;

Jacobs, H. H. (1989). Interdisciplinary curriculum: design and implementation. Alexandria, USA: ASCD

John, Y. J. (2015). A "new" thematic, integrated curriculum for primary schools of Trinidad and Tobago: a paradigm shift. International Journal of Higher Education, Vol. 4, No. 3;

Munroe, A. (2015). Integrated curriculum in the general music classroom. General Music Today, Vol. 29 (1), pag. 12-18; 
Noy, C. (2008). Sampling knowledge: the hermeneutics of snowball sampling in qualitative research. International Journal of Social Research Methodology, 11(4), 327-344;

Potolea, D. (1983). Interdisciplinaritatea conținutului învățământului; o tipologie și câteva implicații. Revista de Pedagogie nr. 8, pg. 58-62;

Potolea, D, Toma, S., Borzea, A. (coord.). (2012). Coordonate ale unui nou cadru de referinţă al curriculumului naţional, Bucureşti: CNEE;

Stohlman, M., Moore, T.J., Roehrig, G. H. (2012). Considerations for teaching integrated STEM education. Journal of Pre-College Engineering Education Research (J-PEER). Vol. 2, Issue 1, pg. 2-34;

Wagner, T., Baum, L., Newbill, P. (2014). From rhetoric to real world: fostering higher order thinking through trans disciplinary collaboration. Innovation in Education and Teaching International, vol. 51, no. 664-673;

*** ISE (2015). Repere pentru proiectarea și actualizarea Curriculumului Național. Document de politici eduaționale. Versiune de lucru. Retrieved from: https://www.ise.ro/wp-content/uploads/2015/12/Document-politicicurriculum final 23decembrie.pdf;

*** OMEN 4828 privind modificarea și completarea Ordinului ministrului educației naționale și cercetării științifice nr. 3590, privind aprobarea planurilor-cadru de învățământ pentru învăţământul gimnazial RO (2018).

Retrieved from $\quad$ http://programe.ise.ro/Portals/1/Curriculum/Pl_cadruactuale/Gimnaziu/OMENCS\%203590 5\%20apr\%202016 Plancadru $\% 20 \mathrm{de} \% 20 \% \mathrm{C} 3 \%$ AEnvatamant $\% 20$ pentru $\% 20$ gimnaziu.pdf;

*** OMENCS nr. 3590 privind aprobarea planurilor-cadru de învățământ pentru învățământul gimnazial RO (2016).

Retrieved from $\quad \underline{\mathrm{http}}$ //programe.ise.ro/Portals/1/Curriculum/Pl_cadruactuale/Gimnaziu/omen-4828.pdf; 